Does suppuration ever occur during the progress of acute rheumatic inflammation in the joints, the eye, the pericardium, or pleura, or in any other structures of the body? Mr. Adams believes that suppuration never does occur as the result of rheumatic inflammation in any organ or tissue of the body, but that rheumatic inflammation always exhibits the same tendency to terminate in the effusion of serum, and plastic lymph, by the organisations of which adhesions are formed.

In the eye, the ophthalmic surgeon has no fear that rheumatic iritis will terminate in suppuration or ulceration; its termination in adhesion is constantly seen, and its prevention is the chief object of treatment. In the pericardium and pleura, when attacked by rheumatic inflammation, the physician looks forward to the same termination. Rheumatic inflammation, therefore, exhibits itself essentially as a productive process, and strumous inflammation as a destructive process.

In the general pathology of rheumatism, it is of importance to ascertain whether there are any modifying influences which may alter the ordinary progress and termination of rheumatic inflammation. The most important modifying influences are those of struma, syphilis, gonorrhœa, and leucorrhoea. Of these it may be said that none of them produce any essential modification as to the results of the rheumatic inflammation. No tendency to suppuration or ulceration is induced by any of these complications, but still each of them exerts some special influence on the progress of the rheumatic inflammation.

Mr. Adams proceeded to the description of Acute Rheumatic Synovitis: its general characters, symptoms, and progress. The doubt expressed by the late Dr. Todd, as to the true inflammatory nature of the jointaffection, was removed, by reference to the post mortern examinations of several patients who had died from cerebral or cardiac complications of rheumatic fever, from the fourth to the twenty-fifth day. In all these examinations, the morbid appearances were essentially of a similar character, viz., inflammation of the synovial membrane, with effusion into the joint of serum, with albuminous shreds, or flocculi of lymph floating in it. In no instance was the existence of pus, or of any ulceration of the articular cartilage described. Mr. Adams regretted that so few post mortem examinations were on record, in which the joints had been examined in patients who had died during an attack of rheumatic fever.

In the treatment, he spoke of the value of the hot-air bath, applied whilst the patient is in bed, and alkaline fomentations to the inflamed joints. The action of alkalies, both externally and internally, he believed was not so much in neutralising the excess of acid in the system, as in their tendency to fluidise the blood, by their direct chemical action upon the fibrine, which is known to be much increased in quantity in this affection; the effect of this in the local application was to remove the condition of stasis of the blood-corpuscles, always existing in in flammation. The action of mercury was also discussed in reference to its power of diminishing the quantity of lymph effused, of preventing its organisation, and promoting its absorption, especial reference being made to the experience of ophthalmic surgeons in the treatment of rheumatic iritis.

The next affection described by Mr. Adams, was Acute Rheumatic Synovitis in an Aggravated Form, Localised in one foint during the early stage of Rheumatic Fever, Gonorrhoal, or Genital Rheumatism. These cases at their commencement exhibit the ordinary symptoms of rheumatic fever; but, instead of metastasis of the articular inflammation occurring, the inflammation in an aggravated form quickly localises itself in one joint, usually the knee or the hip-joint; so that the jointaffection quickly becomes the predominant feature. The acute symptoms generally continue from three to five months. Suppuration is often feared, but no liability to this process exists. It terminates neither in suppuration nor in ulceration, but in the effusion of lymph and organisation of adhesions within and surrounding the joint. A specimen, exhibiting these conditions, was shown to the Society.

The most frequent cause of this affection is the previous existence of gonorrhœa, but sometimes a history of leucorrhœa only can be traced. Hence the propriety of the term genital rheumatism The explanation of these cases, depending upon a mild form of purulent infection, was considered by Mr. Adams as very doubtful, as only one joint is usually affected, and there is no tendency to suppuration; whilst, in pyæmia, several joints are generally involved, and suppuration constantly follows; the pathology is therefore obscure.

The constitutional and local treatment are the same as in the ordinary form of acute rheumatic synovitis, but the intense pain can be best relieved by the subcutaneous injection of morphia. Possibly, the American plan of extension by weights, proved to be so successful in removing the most acute pain of hip-joint disease, and also the pain in some cases of inflammation of the knee-joint, might meet with equal success in this affection, and is worthy of trial.

For the removal of the remaining stiffness of the joint, the use of the steam-bath, shampooing, and passive motion were recommended to be commenced early; and, if these failed, forcible extension under chloroform was to be used, and repeated every two or three weeks, very little being attempted each time, the restoration of motion thus being very slowly and gradually obtained.

\section{ON THE TREATMENT OF CHOLERA.}

\author{
By AQUILLA SMITH, M.D., \\ King's Professor of Materia Medica in Trinity College, and Physician to \\ Sir Patrick Dun's Hospital, Dublin.
}

THE records of Medicine furnish many instances in which writers at an early period, without any knowledge of pathology or of the many other appliances of modern science to the art of medicine, have shown that they were not inferior to practitioners of our own time as close observers of many diseases; and that they occasionally adopted modes of treatment which have been revived in modern times, or unconsciously put forward as original views based on the accumulated experience of modern observers. As an example of a clear and accurate description of ordinary cholera, I quote the following from Aëtius, who, according to Le Clerc, flourished in the fourth century; while Freind asserts, "It is plain, even from his own books, that he did not write till the very end of the fifth or the beginning of the sixth century." (History of Physic, 2nd edit., vol. i, p. 4.)

"Cholera appellatur, quum ob multas cruditates vomitus biliosus et nidorosus et acidus aboritur, ad plures horas continuè perseverans, et venter infernè eadem excernit : sequiturque sitis, et exudatio, et impeditus pulsus, musculorumque manuum ac pedum, maximè verò surarum contractio et tensio. Siquis igitur mox in principio aut coacervatim, ea quæ efferuntur cohibere aggrediatur, is majoris mali auctor erit: inutilia enim quum sint, evacuatione opus habent. Quare convenit, si non sponte ferantur, opportunè irritare, aquâ tepidâ exhibitâ, ac ægro vomere jusso. Aqua enim mulsa mordacitatem operatur, torsionesque auget: aqua verò oleo mixta, auget fluxiones. Quare aquâ tepidâ potatâ vomant, quotiescunque quidem cibis nimiùm fuerint expleti, priusquàm illi corrumpantur. Adjuvare etiam oportet per sedem excretionem; alienum enim velut venenum insidens, et ventrem ac intestina rodit. Per vomitus itaque opportunam provocationem, vomitus ipse solvitur et cessat, et humores ex universo corpore attrahit. - At vero ubi intolerabilis effusio existat, et pulsus emolliatur, apprehendatque frigiditas et exudatio, aliquando etiam singultus, ad vinum transeundum est mediocriter adstringens. - Vini multitudo vitanda est, ac omni arte conandum ut ipsos sopiamus.-Alvo autem adhuc egerente, amylum cum decoctione capitum papaveris per clysterem infundatur: simul enim et cohibet et refrigerrat, et somnum inducit." (Medica Artis Principes, fol., 1567; Aëtius, Tetrabiblos, iii, Sermo i, cap. xii, p. 45o.)

This description of cholera corresponds in the following particulars with the disease with which we have been for some years past too familiar; viz., vomiting and purging, continuing for many hours; thirst and sweating; an embarrassed pulse; cramps, chiefly in the legs; coldness; and at times hiccup.

Epidemics of cholera and fever bear so close a relation to sporadic cases, when one or the other occurs in a severe form, it may be assumed that the principles of treatment which are applicable to the sporadic form of cholera may be resorted to when the disease is epidemic. Sir Thomas Watson, in "A Lecture on Cholera and Diarrhcea", published in the BRITISH MEDICAL JourNaL of July I 8 th, I 868 , admits that he finds " it necessary to modify considerably some advice that he formerly gave as to the treatment of a disorder which appears to be again increasingly prevalent throughout the country," and to a great extent adopts the views of Dr. George Johnson "On the Pathology and Treatment of Cholera", published in the Medico-Chirurgical Transactions, vol. L. Dr. Johnson says: "I will proceed at once to state the main conclusions at which, after a careful study of the disease, I have myself arrived, together with the reasons which have led me to these conclusions. Upon them I invite comment and criticism." (P. IO3.) It is not my purpose to impugn any of the opinions set forth by Dr. Johnson, but merely to "comment" on them so far as to show that, in some respects, they were anticipated by Aëtius about the beginning of the sixth century.

Dr. Johnson's first proposition is, that "the phenomena of cholera result from the action of a morbid poison" (p. IO3); which differs little from "alienum enim valet venenum insidens, et ventrem ac intestina rodit, et humores ex universo corpore attrahit."

Dr. Johnson also says that "the action of repressive drugs, while the cause [of diarrhœa] continues in operation, is either nil or mischievous" 
(p. 123); and Aëtius expresses a similar opinion in very decided terms : "Siquis igitur mox in principio aut coacervatim, ea quæ efferentur cohibere aggrediatur, is majoris mali auctor erit."

Finally, Dr. Johnson says, "There is no disease which so forcibly impresses upon us the necessity of a cathartic method of treatment, in the widest sense of that term" (p. 125); while Aëtius says, "Adjuvare etiam oportet per sedem excretionem."

Aëtius, having condemned "repressive drugs", and prorounced them to be useless, tells us that the patients "evacuatione opus habent", and advises that, when the discharges are not freely carried off, vomiting should be excited by tepid water, and the patient be directed to vomit. $\mathrm{He}$ objects to sweetened water, but recommends "aqua verò oleo mixta", which " auget fluxiones"; and adds, "Per vomitus itaque opportunam provocationem, vomitus ipse solvitur et cessat."

I may add, that Aëtius recommends, in the advanced stage of the disease, the moderate use of a mild astringent wine; and that an attempt should be made to procure sleep, for which purpose he prescribes a decoction of poppy-heads with starch to be administered as an enema.

It is warthy of observation, that every particular of the treatment of cholera recommended in the brief account of the disease given by Aëtius is sanctioned by the high and respected authority of Sir Thomas Watson.

\section{ON THE USE OF OBSTETRIC INSTRUMENTS. *}

BY JOSEPH GRIFFITHS SWAYNE, M.D.,

Physician-Accoucheur to the Bristol General Hospital; and Lecturer on Midwifery at the Bristol Medical School.

IN treating of obstetric instruments and their use, I intend to restrict my observations to those which are employed in assisting labour, and to give as much as possible the results of my own experience as to the best manner of using them. I propose taking the stages of labour in the order in which they occur, and describing the instruments which are adapted to each. In the first stage of labour artificial assistance is scarcely ever necessary, because delay in this stage seldom arises from mechanical obstacles, and is very rarely dangerous as it is in a protracted second stage. Still, however, it is sometimes necessary to have recourse to artificial dilatation of the os uteri. The cases requiring such aid are of three kinds. In the first class of cases we have to anticipate nature, and commence dilating the os uteri artificially; as, for instance, in the induction of premature labour. In the second class, we have to assist the powers of nature when they are inert and sluggish, or when they meet with a greater mechanical obstacle than they can overcome, as in protracted first stage from inefficient uterine action, or from rigidity of the os uteri. In the third class, we are obliged to hasten the natural process of dilatation on account of complications, such as convulsions, which render a speedy termination of the labour necessary. The instruments for accomplishing these purposes are various. They effect their object as dilators by powers of expansion which are the result either of inherent elasticity, or of their capability of being distended by fluids injected into them. Accoucheurs have at different times invented a great variety of these dilators; but those which have now come into common use are of three kinds, and have all in turns been employed by me according to the exigencies of each particular case. When the os uteri is so contracted that it will not admit the tip of the index finger, dilators of the smallest and most rigid kind must be had recourse to. For this purpose none are so good as tents made of the dried stem of the sea-tangle (Laminaria digitata). These are much more expansible, and therefore much superior to those made of gentian-root, which, until lately, were more commonly used than any other vegetable substance for the purposes of dilatation. They are readily obtained at most surgical instrument makers' shops, where small boxes are usually sold containing ten or a dozen pieces of tangle, most of which are about one and a half inch in length, and about the thickness of a porcupine quill. When one of these pieces of tangle is inserted into the os uteri, and left there for some hours, it will imbibe moisture and swell to the size of a man's fore-finger. They are easily introduced into the os uteri, but not so easily retained, for their hard polished surface causes them to be readily extruded, and it is generally necessary to keep them in situ by means of a plug. The best mode of introducing them is to pass them up through a full-sized speculum, by means of a dressing, or polypus-forceps. A soft silk handkerchief, previously well oiled, should then be passed up to keep the tent in situ, and the speculum withdrawn. Some improvements have of late years been made in the laminaria tents ; for instance, Dr. Greenhalgh, at one of the meetings of the Obstetrical Society, in

\footnotetext{
- Read before the Bath and Bristol Branch.
}

1865, exhibited a new form of Uterine Tent, made from the stem of the Laminaria spiralis; the peculiarity being, that it was a hollow tube instead of the solid stick heretofore used; and, at a subsequent meeting in the same year, Dr. Barnes showed an instrument made for him by Messrs Weiss, for the purpose of facilitating the introduction of the perforated laminaria tent. It consisted of a wire stem, on which the tent was mounted, connected with a flexible tube like a catheter. The tent thus supported was introduced into the os uteri as easily as an uterine sound, and being there, by pushing up the flexible tube, the wire was withdrawn from the tent, leaving this in situ.

In cases, however, which require a greater amount of dilatation, something more efficient than the tangle tents must be used, and for this purpose nothing is better than pieces of compressed sponge. These may be made of various sizes and lengths, from an inch long, for instance, to as much as two inches and a half. They may be bought ready made; but, for my own part, I always prefer making them myself, which I do in the following manner. Having selected a conical piece of sponge of firm texture, and not exceeding two and a half inches in length and two in thickness at the base, pass a strong loop of tape through the base of the tent. This is for the purpose of withdrawing it after it has dilated to its full extent. The sponge, previously well washed and cleansed, is then to be dipped in a solution of gum arabic of the consistence of thick syrup. A metal stilette, previously well greased, is then to be thrust down its centre from the base nearly to the apex. For this purpose an ordinary kitchen skewer will answer very well. The sponge is then to be compressed firmly by a piece of strong whipcord, which is to be rolled round it very tightly in regular spirals, lying close to each other, from the apex to the base of the cone, where it is fastened off, much in the same way as a boy would wind a piece of string round a peg-top. After this the tent is to be put in an oven or on the hob of a fire-grate and left until it is quite dry. The cord is then unwound and the stillette withdrawn. After the inequalities on its surface have been removed by a rasp, the tent should be smeared with cerate or with spermaceti ointment, and is then ready for use. To apply it, it should be mounted on an uterine or an ordinary metal sound. If the os uteri be very high and the tent required be small, it will be more convenient to pass it up through a full-sized tube speculum. If, however, the os uteri be somewhat dilated, so as to admit one or two fingers, the tent required will be too large to introduce properly in this way. The best plan, then, is to place the woman on her left side, in the ordinary obstetric position. Having inserted the tips of the fore and middle fingers of the left hand into the os uteri, pass the tent up along the groove between the two fingers into the os uteri nearly as far as the base of the cone. A silk handkerchief, well oiled, is then to be introduced into the vagina as a plug to keep the tent in its place. When the plug can be inserted through a speculum the operation is rendered much easier, and is much less painful for the patient. After the tent has remained some time in the os uteri it absorbs the moisture secreted by the part, the gum arabic is slowly dissolved, and the sponge, thus released from the power which held it together, swells by its own elasticity to four or five times its bulk in the dried state, and thus most effectually dilates the canal of the cervix. There is one great objection to sponge-tents, however, and that is the horribly offensive odour which they acquire after they have been retained many hours in the vagina; and there is, indeed, some danger from absorption of the putrid discharges which are thus kept in contact with the mucous surface. On that account, I make it a rule never to leave one of these tents longer than twelve hours in the cervix uteri, but always remove it before that time, and substitute a fresh one if required. Certain improvements have recently been made in the sponge-tents, principally with a view to obviate this inconvenience. For instance, Dr. Aveling deodorises them by introducing into their central canal about two grains of finely powdered permanganate of potash, and this. is found to answer the purpose very well. Mr. Ellis prefers carbolic acid, and uses the cacao butter or oil of theobroma, in preference to mucilage of gum arabic, for keeping the tent together. About a drachm and $a$ half of pure crystalline carbolic acid is to be mixed with an ounce of the butter, whilst kept in a fluid state by being held over a small flame or placed in a hot water bath. In making the tent, the dried sponge is to be folded round a metal stilette, and compressed by winding. tape round it. It is then to be immersed in the melted cacao butter "for a few seconds, so as to saturate only the outer layer of the sponge, and this it does, penetrating readily through the tape. The tent is then placed in a very cool place, and, after it has solidified, the tape is cut and unrolled. All that is now necessary to complete it is to dip it once more into the same preparation-which for this latter purpose must be much cooler than before, and of about the consistency of cream. By this means a smooth and uniform covering is given to the tent, and it is ready for use." (Obstetrical Transactions, vol. ix.) Mr. Ellis lays great stress upon the adrantages of making these tents of an ovoid form, so as to 